\title{
Firm's Risk and Capital Structure: An Empirical Analysis of Seasonal and Non-Seasonal Businesses
}

\author{
Safdar Husain TAHIR ${ }^{1}$, Mirza Muhammad MOAZZAM², Nayyer SULTANA², \\ Gulzar AHMAD ${ }^{4}$, Ghulam SHABIR ${ }^{5}$, Filza NOSHEEN ${ }^{6}$
}

Received: September 10, 2020 Revised: November 08, 2020 Accepted: November 16, 2020

\begin{abstract}
The study attempts to analyze the impact of firm's risk on capital structure in the context of seasonal and non-seasonal businesses. We use two independent variables namely credit risk and systematic risk and one dependent variable to explore this connection. Sugar sector is taken as seasonal while the textile sector as non-seasonal businesses. The panel data of twenty-five firms from each sector are taken ranging for the period of 2012 to 2019 which has been retrieved from their annual reports for empirical analysis of the study. The results reveal the negative impact of credit risk on capital structure in both types of businesses. Increasing (decreasing) one point of credit risk causes a decrease (increase) leverage ratio by 0.27 points for seasonal while increasing (decreasing) one point of credit risk causes to decrease (increase) leverage by 0.15 points for non-seasonal businesses. Furthermore, the study shows positive impact of systematic risk on leverage ratio in non-seasonal business and no impact in seasonal business. Any increase (decrease) in the systematic risk causes an incline (decline) leverage ratio by 2.68 units for non-seasonal businesses. The study provides a guideline to managers for risk management in businesses. The research focusses on theoretical as well as managerial and policy implications on risk management in businesses.
\end{abstract}

Keywords: Leverage Ratio, Credit Risk, Systematic Risk, Seasonal Business, Non-Seasonal Business

JEL Classification Code: D81, G32, M21

\section{Introduction}

The study focuses on investigation for the impact of credit and systematic risk on capital structure by controlling the effect of firm size and firm growth. It provides a

${ }^{1}$ First Author and Corresponding Author. Associate Professor, Lyallpur Business School, Govt. College University, Faisalabad, Pakistan [Postal Address: Jinnah Street Officer Colony-2 Madina Town, Faisalabad-38860, Punjab, Pakistan] Email: drsafdargcuf@gmail.com ${ }^{2}$ MS-Scholar, Lyallpur Business School, Government College University, Faisalabad, Pakistan. Email: hotmind07@gmail.com

${ }^{3}$ Lecturer, Department Public Administration, Government College Women University, Faisalabad, Pakistan. Email: nyrlashari@gmail.com ${ }^{4}$ Professor, Department of Psychology, Lahore Garrison University, Lahore, Pakistan. Email: gulzar818@gmail.com

${ }^{5}$ MS-Scholar, Lyallpur Business School, Government College University, Faisalabad, Pakistan. Email: shabiralyani@gmail.com

${ }^{6}$ MS-Scholar, Lyallpur Business School, Government College University, Faisalabad, Pakistan. Email: filzanosheen@yahoo.com

(c) Copyright: The Author(s)

This is an Open Access article distributed under the terms of the Creative Commons Attribution Non-Commercial License (https://creativecommons.org/licenses/by-nc/4.0/) which permits unrestricted non-commercial use, distribution, and reproduction in any medium, provided the original work is properly cited. comparative analysis between non-seasonal (textile sector) and seasonal (sugar sector) businesses operating in Pakistan. According to the nature of business, the textile sector (nonseasonal business) operates throughout the year while the sugar sector (seasonal business) operates only for a specific period of time like for a few months.

Capital structure is an essential part for the survival, performance and growth of a business concern. The most important matter and ultimate goal of any business is to maximize the shareholder's wealth. However, there is one factor that may impact the shareholder's wealth and that is the usage of optimum level of debt-equity ratio (Alkhatib, 2012). The cost of capital of the firm varies with the cost of debt and equity, thus capital structure is created on the basis of debt and equity. The firm that takes debt is known as a levered firm while the firm that collects equity funds is known as an unlevered firm. The capital structure of a firm is defined by leverage that is a mixture of equity and debt financing.

Leverage represents the events that determines a firm's source of financing mix to operate the business. Modigliani and Miller (1958) assume that the value of a business is 
independent from its equity and debt mix. However, they ignore issues that play a vital role in explaining the best capital structure like corporate taxes. Sheikh and Wang (2011) specified that corporate taxes depend upon the argument that the WACC (weighted average cost of capital) remains unchanged as leverage varies. Firms possessing a higher level of debt in their capital structure are able to drop their free-cash-flow. Firms through consuming the excessive debt; the free-cash-flow as an alternative of being ineffectually employed by the management given instantaneously to the borrowers and is withdrawn from the company as interest expenses. Capital structure of a firm that contains a higher level of debt-equity ratio tends to incline towards the bankruptcy risk; that is when firm's total debts equal the total assets of the firm (Khan, Kaleem \& Nazir, 2012).

The term risk is generally defined as the volatility of a particular security. Typically, investments have an associated risk based on their market exposure and the instabilities within them. An investment risk is the probability that actual return differs from the expected return. Risk also includes the chances of getting lower returns than the initial investment. The more the returns deviate from the expected returns, the higher is the risk and higher is the reward. The study offers two different approaches of risk; credit and systematic risk.

The credit and systematic risk are widely discussed in the financial debate and considered to be the most interesting and important issue in the studies of stock markets (Kim, Gu $\&$ Mattila, 2002). The term credit is defined as the provision of resources in which one party grants loan to another party. The second party does not repay the loan immediately and generates a debt. The borrower arranges either to return or repay those resources or loan amount of equal value at some future date. Credit risk (CR) is a risk of impairment rising from a borrower who does not repay the loan at a promised future date. The lender loses the owed principal as well as interest, it results in decreased cash flow and increased collection cost (Al-Tamimi \& Al-Mazrooei, 2007). The classical notation of systematic risk reflects an asset's contribution to the portfolio risk. Traditional measures of systematic risk emphasize on a specific set of attributes of risk. Particularly, most widely used and well-known measure of systematic risk is asset's beta. An asset's beta is the slope that regress the return on assets of portfolio return (Mossin, 1966; Sharpe, 1964). Beta is basis for all the analysis of riskreturn as a portion of the capital asset pricing model. Though, the traditional beta disregards all features of risk other than variance like rare disaster and higher distribution moments.

\subsection{Problem Statement}

Risk and capital structure play a vital role in financing decisions. Many firms (seasonal and non-seasonal) face financial difficulties in terms of risk but in different aspects.
In this regard, there is a need for the awareness of risk for decision makers. Therefore, it is valuable to find the relationship between risk and capital structure under sectoral differences of sugar (seasonal) and textile sector (nonseasonal) in the context of Pakistan.

\subsection{Research Objectives}

The prime aim of the research is to evaluate the effect of risk on capital structure. Therefore, the study also fulfills the following objectives:

- To investigate the impact of credit risk (CR) on leverage (LV).

- To analyze the effect of systematic risk (SR) on leverage (LV).

- To make comparison between seasonal and non-seasonal businesses.

- To provide useful suggestions and recommendations to policy makers and for future researchers in context of seasonal and non-seasonal businesses.

\section{Literature Review}

The capital structure of an organization is distinct by its leverage that is a combination of debt and equity mix which is concerned with diverse fiscal implications. Financial leverage ratio denotes the total liability described to equity of a firm, replicating the skill of the financial executives to invite investments from external investors. Modigliani and Miller (1958) stated that CS (capital structure) is unrelated in a trade world deprived of transaction charges, taxes or additional market deficit.

\subsection{Credit Risk and Capital Structure (Leverage)}

Iqbal and Kume (2015) explored the effect of definite features on credit risk by using multivariate regression analysis. They used 22 non-financial firms as study samples. They found a negative relationship between capital structure and credit risk. Srivastava (2014) investigated the determinants of leverage of Indian firms. The determinants of leverage were profitability, firm size, tangibility, growth, liquidity and credit risk. The impact of these variables were analyzed through the linear regression model. They indicated that there was a negative impact of these variables on the leverage. Danila et al. (2020) also found a significant effect of credit risk on leverage.

Gilchrist and Mojon (2018) revealed that the credit risk increased from the nature of agreements. They selected credit risk pointers for Euro area banks and non-financial firms. They investigated the normal extents on the yield of Euro area private sector in relation to the revenue of German federal government securities. They indicated that the 
economic crisis of 2008 had an adverse impact on the market of banks and non-financial firms. They found an indirect association between leverage and credit risk. Imbierowicz and Rauch (2014) also found an indirect connection between credit risk and debt-equity ratio.

Buchdadi et al. (2020) studied the association among capital adequacy ratio, debt to equity ratio and credit risk of nine banks by using non-performing loan as an indicator of bank credit risk. The study's pooled OLS regression showed the significant relation between debt to equity ratio and credit risk. Tulcanaza et al. (2019) believed that the external determinants of the capital structure significantly affected credit risk of large corporations listed on the Korean Stock Exchange. Vivel-Búa et al. (2018) found negative influence of leverage on credit risk. Chodnicka-Jaworska and Jaworski (2017) indicated that economic uncertainty and earning potentials positively contributed to the credit risk. They further indicated that capital adequacy ratio had a negative effect on credit risk. Woo et al. (2020) worked on the logistic and shipping industry and found a negative link between leverage and credit risk.

$\boldsymbol{H}_{1}:$ There is a negative impact of credit risk on capital structure (leverage).

\subsection{Systematic Risk and Capital Structure (Leverage)}

Akbari and Mohammadi (2013) showed the association between systematic risk and leverage ratio by using the panel data of 115 companies listed in Tehran Stock Market for the period of 2005 to 2012. The regression analysis was used to analyze the association. They indicated that systematic risk was one of the utmost real aspects in forecasting the suitable mandatory profit rate of portfolios. They discovered a significant and direct association between systematic risk and leverage ratio. Chowdhury and Chowdhury (2010) examined the effect of capital structure on the value of firm and risk. They indicated that maximizing the value of investors' capital needed a perfect arrangement of debt and equity. However, cost of capital had an adverse relationship in this assessment and that had to be decreased. Moreover, they found a positive association of capital structure with risk and firm value.

Mnzava (2009) studied the determinants of systematic risk in the United Kingdom. He tested the significance of leverage as one of the determinants influencing systematic risk by using both cross sectional and time series models involving basic determinants of systematic risk. He found a positive interaction between leverage and systematic risk. He concluded that systematic risk significantly increases the firm's equity betas. Similarly, Ahmad, Ali, Arshad and Shah (2011) and Lee and Jang (2007) also observed a positive association between systematic risk and leverage. Iqbal and Shah (2012) analyzed the relationship among financial variables and systematic risk in 93 non-financial companies listed on the KSE (Karachi Stock Exchange) in Pakistan for the period of 2005-09. They explored operating efficiency of a firm, dividend policy, size of a firm and growth, equitymarket value, liquidity and leverage as financial variables. They did not find any significant association between systematic risk and leverage.

Amiri and FadaeiNejad (2018) worked on the determinants of systematic risk and found that debt ratio, inflation and exchange rate had negative influence on systematic risk. Qin and Zhou (2019) studied the influence of leverage, market to book ratio, firm size, non-performing loan ratios and off sheet business activities on the systematic risk of commercial banks. The results of the study showed that leverage and non-performing loan ratios had negative effects on systematic risk. Jaafar et al. (2020) believed that leverage was the most important factor of systematic risk. Tripathi and Thukral (2018) also revealed the significant linkage between systematic risk and leverage ratio.

$\boldsymbol{H}_{2}:$ There is a direct linkage between systematic risk and capital structure (leverage ratio).

\subsection{Firm Size, Growth and Capital Structure (Leverage)}

Alkhatib (2012) explored the determinants of leverage ratio of 121 companies listed on JSE (Jordanian Stock Exchange) for the period of 2007-10 by using the multiple regression analysis. He concluded a significant interaction between size, growth and financial leverage. Sheikh and Wang (2011) also studied the determinants of capital structure and found a positive impact of firm size on capital structure measured in terms of leverage. Iqbal, Chaudry and Iqbal (2017) indicated a positive relationship among leverage, firm size and firm growth. Iqbal and Shah (2012) investigated the association between firm size, growth and leverage and found positive linkage of firm size and growth with leverage.

\section{Data and Methodology}

The present study has attempted to analyze the impact of credit and systematic risk on capital structure. It provides a comparative analysis between non-seasonal and seasonal businesses of Pakistan. The research was conducted on sugar sector (seasonal) and textile sector (non-seasonal). The firms which fulfilled all the characteristics of the study were chosen as samples. A total of 50 firms ( 25 firms from sugar and 25 firms from textile sector) were selected as samples. The data covered the period of 2012 to 2019. The data were gathered from annual published financial reports of sampled firms. 


\subsection{Variables}

The study used capital structure as a dependent variable while credit risk and systematic risk were used as independent variables. Firm size and firm growth were used as control variables. The description of variables is provided in Table 1.

\subsection{Econometric Model}

The multiple-regression models were applied to analyze the effect of credit and systematic risk on capital structure. The empirical analysis had two steps, first for sugar sector and second for the textile sector. The following equation were estimated separately for sugar and the textile sector:

$$
\begin{aligned}
\mathrm{LV}_{\mathrm{it}}= & \beta_{0}+\beta_{1}\left(\mathrm{CR}_{\mathrm{it}}\right)+\beta_{2}\left(\mathrm{SR}_{\mathrm{it}}\right)+\beta_{3}\left(\mathrm{FS}_{\mathrm{it}}\right) \\
& +\beta_{4}\left(\mathrm{FG}_{\mathrm{it}}\right)+\mathrm{e}_{\mathrm{it}}
\end{aligned}
$$

Where; LV is Leverage, CR is Credit Risk, SR is Systematic Risk, FS is Firm Size, FG is Firm Growth for firm ' $i$ ' and time ' $t$ '. $\beta_{0}, \beta_{1}, \beta_{2}, \beta_{3}$, and $\beta_{0}$ are the coefficients and ' $e$ ' represents the error term.

\section{Empirical Results}

This section shows the empirical results of descriptive statistics, correlation analysis and regression analysis for the impact of credit and systematic risk on capital structure for both the seasonal and non-seasonal businesses.

\subsection{Descriptive Statistics}

Table 2 exhibits the research's outcomes of descriptive statistics for both the seasonal and non-seasonal businesses. The mean value of LV for seasonal (non-seasonal) business is 0.65 (1.06) ranging from $0.00(0.00)$ to $1.51(1.76)$. The LV shows $+3.61 \%$ variations in seasonal business while $+10.65 \%$ variations in non-seasonal businesses. The average value (standard deviation) of CR for seasonal and non-seasonal businesses are $0.03(+0.12)$ and $0.01(+0.04)$ respectively. The mean value of SR is 0.97 for seasonal and 0.21 non-seasonal businesses with the $+6.36 \%$ variations in seasonal and $+0.97 \%$ variations in non-seasonal businesses. The mean value of FS for seasonal (non-seasonal) businesses is 20.78 (21.19) with $+4.37 \%(+4.09 \%)$ variations. The average value (standard deviation) of FG for seasonal and non-seasonal businesses are $0.83(+3.03)$ and $1.67(+10.15)$ respectively.

\subsection{Correlation Analysis}

Table 3 displays the coefficients of Pearson Correlation Matrix for all the variables under study. The correlation analysis is used to detect the multicollinearity among all the variables. The sign of negative or positive with the coefficient shows the direction of the relation. The value of correlation coefficient is less than 0.26 in both seasonal and non-seasonal businesses; it indicates that multicollinearity does not exist in the data.

\subsection{Regression Analysis}

Table 4 provides the regression results for the impact of credit and systematic risk on capital structure for both the seasonal and non-seasonal businesses. There is a significant negative influence of credit risk (CR) on leverage (LV) both in seasonal and non-seasonal businesses. The negative coefficient of $\mathrm{CR}$ shows that increasing (decreasing) one point of CR causes to decrease (increase) LV by 0.27 points for seasonal businesses while increasing (decreasing) one

\begin{tabular}{|c|c|c|c|}
\hline Name of Variables & Proxy & Measurement & Source of definition \\
\hline \multicolumn{4}{|c|}{ Explained Variable } \\
\hline Capital Structure & i. Leverage (LV) & i. Total Debts /Total Assets & $\begin{array}{c}\text { Tahir, Ullah and Mahmood (2015), } \\
\text { Tahir, Ullah and Shah (2017), } \\
\text { Pattiruhu and Paais (2020) }\end{array}$ \\
\hline \multicolumn{4}{|c|}{ Independent Variables } \\
\hline \multirow{2}{*}{ Risk } & i. Credit Risk (CR) & i. Loan Loss Provision/Total Debts & $\begin{array}{l}\text { Srivasrava (2014), Le and Diep } \\
\text { (2020), Iqbal and Kume (2015). }\end{array}$ \\
\hline & $\begin{array}{l}\text { ii. Systematic Risk } \\
\text { (SR) }\end{array}$ & $\begin{array}{c}\text { ii. Beta }=\text { Returns }=\ln \left(\mathrm{P}_{\mathrm{t}} / \mathrm{P}_{\mathrm{t}-1}\right) \\
\text { where: In: logarithm natural }\end{array}$ & $\begin{array}{l}\text { Akbari (2013), } \\
\text { Mnzava (2009). }\end{array}$ \\
\hline \multicolumn{4}{|c|}{ Control Variables } \\
\hline \multirow[b]{2}{*}{ Control Variables } & i. Firm Size (FS) & i. In (Total Assets) & Tahir, Ullah and Mahmood (2015) \\
\hline & ii. Firm Growth (FG) & $\begin{array}{l}\text { ii. }\left(\text { Sales }_{t}-\text { Sales }_{t-1}\right) / \text { Sales }_{t-1} \\
\text { where; current year }=t \text {, } \\
\text { previous year }=\mathrm{t}-1\end{array}$ & $\begin{array}{l}\text { Tahir, Ullah and Mahmood (2015), } \\
\text { Danila et al. (2020). }\end{array}$ \\
\hline
\end{tabular}

Table 1: Variables Description 
Table 2: Descriptive Statistics

\begin{tabular}{|l|c|c|c|c|c|c|c|c|c|c|}
\hline \multicolumn{5}{|c|}{ Sugar Sector (Seasonal) } & \multicolumn{4}{c|}{ Textile Sector (Non-Seasonal) } \\
\hline Variables & LV & CR & SR & FS & FG & LV & CR & SR & FS & FG \\
\hline Mean & 0.6517 & 0.0256 & 0.9736 & 20.7800 & 0.8326 & 1.0607 & 0.0070 & 0.2119 & 21.1904 & 1.6797 \\
\hline Median & 0.2339 & 0.1547 & 0.0787 & 21.7309 & 0.2658 & 0.1272 & 0.2148 & 0.1140 & 21.9527 & 0.1784 \\
\hline Maximum & 1.5065 & 1.1043 & 3.4014 & 24.3451 & 20.3146 & 1.7616 & 0.4764 & 4.5838 & 24.9433 & 28.8952 \\
\hline Minimum & 0.0000 & 0.0000 & 1.2487 & 6.3685 & -1.1587 & 0.0000 & 0.0000 & -3.0695 & 7.7586 & -1.4751 \\
\hline Std. Dev. & 3.6160 & 0.1229 & 6.6364 & 4.3779 & 3.0319 & 10.6526 & 0.0424 & 0.9678 & 4.0921 & 10.1539 \\
\hline
\end{tabular}

Table 3: Pearson Correlation Matrix

\begin{tabular}{|l|c|c|c|c|c|c|c|c|c|c|c|}
\hline \multicolumn{9}{|c|}{ Sugar Sector (Seasonal) } & \multicolumn{5}{c|}{ Textile Sector (Non-Seasonal) } \\
\hline Variables & LV & CR & FG & FS & SR & Variables & LV & CR & FG & FS & SR \\
\hline LV & 1.0000 & & & & & LV & 1.0000 & & & & \\
\hline CR & -0.0288 & 1.0000 & & & & CR & -0.0155 & 1.0000 & & & \\
\hline FG & -0.0270 & -0.0511 & 1.0000 & & & FG & -0.0190 & -0.0278 & 1.0000 & & \\
\hline FS & -0.0040 & 0.0253 & -0.1343 & 1.0000 & & FS & -0.1187 & 0.0556 & 0.0078 & 1.0000 & \\
\hline SR & -0.0033 & -0.0212 & 0.0363 & -0.0054 & 1.0000 & SR & 0.2571 & -0.0778 & -0.0123 & -0.0791 & 1.0000 \\
\hline
\end{tabular}

Table 4: Regression Analysis

\begin{tabular}{|c|c|c|c|c|c|c|c|c|}
\hline \multirow{2}{*}{ Variables } & \multicolumn{4}{|c|}{$\begin{array}{l}\text { Sugar Sector (Seasonal) } \\
\text { [Dependent Variable: LV] }\end{array}$} & \multicolumn{4}{|c|}{$\begin{array}{l}\text { Textile Sector (Non-Seasonal) } \\
\text { [Dependent Variable: LV] }\end{array}$} \\
\hline & Coeff & Std. Error & T-Stat & PV & Coeff & Std. Error & T-Stat & PV \\
\hline Constant & 5.3725 & 2.0270 & 2.6504 & $0.0087^{* * *}$ & 6.0052 & 2.3652 & 2.5390 & $0.0079^{* * *}$ \\
\hline CR & -0.2690 & 0.0649 & -4.1420 & $0.0000^{\star * *}$ & -0.1502 & 0.0480 & -3.1236 & $0.0000^{\star * *}$ \\
\hline SR & -0.0026 & 0.7879 & -0.7675 & 0.4437 & 2.6832 & 0.7633 & 3.5152 & $0.0005^{* * *}$ \\
\hline FS & 0.0175 & 0.0131 & 1.3340 & 0.1838 & -0.2596 & 0.1803 & -1.4404 & 0.1514 \\
\hline FG & -0.0271 & 0.0133 & -2.0463 & $0.0421^{\star \star}$ & -0.1423 & 0.0675 & -2.1055 & $0.0361^{* *}$ \\
\hline \multicolumn{3}{|c|}{$\mathrm{R}^{2}$} & \multicolumn{2}{|c|}{0.5751} & \multicolumn{2}{|c|}{$\mathrm{R}^{2}$} & \multicolumn{2}{|c|}{0.7322} \\
\hline \multicolumn{3}{|c|}{$R^{2}$ (adjusted) } & \multicolumn{2}{|c|}{0.5147} & \multicolumn{2}{|c|}{$\mathrm{R}^{2}$ (Adjusted) } & \multicolumn{2}{|c|}{0.5421} \\
\hline
\end{tabular}

point of CR causes to decrease (increase) LV by 0.15 points for non-seasonal business. The systematic risk (SR) has significant positive impact on LV in non-seasonal businesses but has no impact in seasonal businesses. The positive coefficient of SR indicates that any increase (decrease) in the SR causes to incline (decline) LV by 2.68 units for non-seasonal businesses. Moreover, firm growth (FG) has significant negative impact on capital structure (leverage) and firm size (FS) has insignificant impact on capital structure in both the seasonal and non-seasonal businesses.

\section{Discussions and Conclusions}

The study focuses on investigation for the impact of credit and systematic risk on capital structure by controlling the effect of firm size and firm growth. It provides a comparative analysis between non-seasonal (textile sector) and seasonal (sugar sector) businesses operating in Pakistan. According to the nature of business, textile sector (non-seasonal business) operates throughout the year while the sugar sector (seasonal business) operates only for a specific period of time like for a few months. 
There is a significant negative influence of credit risk (CR) on leverage (LV) both in seasonal and non-seasonal businesses. The negative coefficient of CR shows that increasing (decreasing) one point of CR causes to decrease (increase) LV by 0.27 points for seasonal business while increasing (decreasing) one point of CR causes to decrease (increase) LV by 0.15 points for non-seasonal business. These findings are consistent with previous empirical literature (Iqbal \& Kume, 2015; Srivastava, 2014; Danila et al., 2020; Gilchrist \& Mojon, 2018; Imbierowicz \& Rauch, 2014; Buchdadi et al., 2020; Tulcanaza et al., 2019; Vivel-Búa et al., 2018; Chodnicka-Jaworska \& Jaworski, 2017; Woo et al., 2020) and also support the hypothesis-1. The selected firms hold a larger amount of capital as an incentive to avoid failure. The results represent that managers consider business risks while deciding about their company's capital structure. When the earnings become highly unstable, managers tend to reduce the debt level to avoid the bankruptcy risk. Executives of both seasonal and non-seasonal businesses are deeply concerned with the risk related elements and they act in a risk averse manner. The reason behind acting as risk averse is to avoid the uncertainty dominating the economy of Pakistan. As the attitude of managers is risk averse, the lenders try to increase the loan limit but the managers do not extend their level of debt beyond a specific limit to avoid bankruptcy risk. The lenders may feel free to lend their surplus money to textile and sugar sector firms listed on the Pakistan Stock Exchange.

The SR has a significant positive impact on LV in nonseasonal business but has no impact in seasonal business. The positive coefficient of SR indicates that any increase (decrease) in the SR causes to incline (decline) LV by 2.68 units for non-seasonal businesses. The findings are similar with previous studies (Akbari \& Mohammadi, 2013; Chowdhury \& Chowdhury, 2010; Mnzava, 2009; Ahmad et al., 2011; Lee \& Jang, 2007) which confirm the hypothesis-2. Managers of non-seasonal business firms perhaps do participate in trade-off to maintain and control the strategically selected level of systematic risk. Consequently, the strategic opinion of capital structure is slightly evidenced in the present study. These findings reveal something about the change in the systematic risks of the businesses, "risks of portfolios of projects held' in Pakistani non-seasonal business firms. Similarly, the results reveal a great deal about inseparability of the financing and investment decisions in Pakistani setting.

Moreover, firm growth has a significant negative impact on capital structure (leverage) both in non-seasonal and seasonal businesses of Pakistan. The managers of seasonal and non-seasonal businesses should try to maintain a specific level of company's growth. The use of debt financing in the markets of Pakistan is considered as one of the approaches to minimize the level of risk. Although, that mechanism forces the managers to enhance their profitability so that they can save much more as retained earnings, to maintain the level of organization's growth.

\section{References}

Ahmad, F., Ali, M., Arshad, M. U., \& Shah, S. Z. A. (2011). Corporate tax rate as a determinant of systematic risk: Evidence from Pakistani cement sector. African Journal of Business Management, 5(33), 12762-12767. https://doi.org/10.5897/ AJBM11.666

Akbari, P., \& Mohammadi, E. (2013). A study of the effects of leverages ratio on systematic risk based on the capital asset pricing model among accepted companies in Tehran stock market. J. Educ. Manage. Stud., 3(4), 271-277. https://ssrn. com/abstract $=2156833$

Alkhatib, K. (2012). The determinants of leverage of listed companies. International Journal of Business and Social Science, 3(24), 78-83. http://ijbssnet.com/journals/Vol_3_ No_24_Special_Issue_December_2012/8.pdf

Al-Tamimi, H., \& Al-Mazrooei M. (2007). Banks' Risk Management: A Comparison Study of UAE National and Foreign Banks. The Journal of Risk Finance, 8(4), 394-409. https://doi.org/10.1108/15265940710777333

Amiri, A. A., \& FadaeiNejad, M. E. (2018). Determinants of systematic risk in the Iranian Financial sector. Iranian Journal of Finance, 2(1), 59-79. https://dx.doi.org/10.22034/ ijf.2018.84949

Buchdadi, A., Nguyen, X., Putra, F., \& Dalimunthe, S. (2020). The effect of credit risk and capital adequacy on financial distress in rural banks. Accounting, 6(6), 967-974. http://dx.doi. org/10.5267/j.ac.2020.7.023

Chodnicka-Jaworska, P., \& Jaworski, P. (2017). Fundamental determinants of credit default risk for European and American banks. Journal of International Studies, 10(3), 51-63. https:// doi.org/10.14254/2071-8330.2017/10-3/4

Chowdhury, A., \& Chowdhury, S. P. (2010). Impact of capital structure on firm's value: Evidence from Bangladesh. Business \& Economic Horizons, 3(3). 111-122. https://www.ceeol.com/ search/article-detail?id=24300

Danila, N., Noreen, U., Azizan, N. A., Farid, M., Ahmed, Z., Pattiruhu, J. R., \& Arisman, A. (2020). Growth Opportunities, Capital Structure and Dividend Policy in Emerging Market: Indonesia Case Study. Journal of Asian Finance, Economics and Business, 7(10), 1-8. https://doi.org/10.13106/jafeb.2020. vol7.no10.001

Gilchrist, S., \& Mojon, B. (2018). Credit risk in the euro area. The Economic Journal, 128(608), 118-158. https://doi.org/10.1111/ ecoj. 12427

Imbierowicz, B., \& Rauch, C. (2014). The relationship between liquidity risk and credit risk in banks. Journal of 
Banking \& Finance, 40, 242-256. https://doi.org/10.1016/j. jbankfin.2013.11.030

Iqbal, A., \& Kume, O. (2015). Impact of financial crisis on firms' capital structure in UK, France, and Germany. Multinational Finance Journal, 18(3), 249-280. https://ssrn.com/ abstract $=2619193$

Iqbal, M. J., \& Shah, S. Z. A. (2012). Determinants of systematic risk. The Journal of Commerce, 4(1), 47-56. http://joc.hcc.edu. pk/articlepdf/joc201260_47_56.pdf

Iqbal, S., Chaudry, S. N. \& Iqbal, N. (2017). Impact of liquidity risk on firm specific factors: A case of Islamic banks of Pakistan. European Journal of Business and Innovation Research, 5(6), 40-45. https://www.eajournals.org

Jaafar, M. N., Muhamat, A. A., Basri, M. F., \& Alwi, S. F. S. (2020). Determinants of Systematic Risk: Empirical Evidence from Shariah Compliants Firms Listed on Bursa Malaysia. International Business Education Journal, 13(1), 71-82. https://ejournal.upsi.edu.my/index.php/IBEJ/article/view/3413

Khan, A., Kaleem, A., \& Nazir, M. S. (2012). Impact of Financial Leverage on Agency cost of Free Cash Flow: Evidence from the Manufacturing sector of Pakistan. Journal of Basic and Applied Scientific Research, 2(7), 6694- 6700. https://www. textroad.com/JBASR-July,\%202012(2).html

Kim, H., Gu, Z., \& Mattila, A. S. (2002). Hotel real estate investment trusts' risk features and beta determinants. Journal of Hospitality and Tourism Research, 26(2), 138-154. https:// doi.org/10.1177/1096348002026002004

Le, T. T. D., \& Diep, T. T. (2020). The effect of lending structure concentration on credit risk: The evidence of Vietnamese commercial banks. Journal of Asian Finance, Economics, and Business, 7(7), 59-72. https://doi.org/10.13106/jafeb.2020. vol7.no7.059

Lee, J. S., \& Jang, S. S. (2007). The systematic-risk determinants of the US airline industry. Tourism Management, 28(2), 434-442. https://doi.org/10.1016/j.tourman.2006.03.012

Mnzava, I. D. (2009). The Significance of Corporation Tax as a determinant of Systematic Risk: Evidence using United Kingdom (UK) data. KCA Journal of Business Management, 2(1), 44-61. https://doi.org/10.4314/kjbm.v2i1.44410

Modigliani, F., \& Miller, M. H. (1958). The cost of capital, corporation finance and the theory of investment. The American Economic Review, 48(3), 261-297. https://www.jstor.org/ stable/1809766

Mossin, J. (1966). Equilibrium in a capital asset market. Econometrica: Journal of the Econometric Society, 768-783. https://doi.org/10.2307/1910098
Pattiruhu, J. R., \& Paais, M. (2020). Effect of Liquidity, Profitability, Leverage, and Firm Size on Dividend Policy. Journal of Asian Finance, Economics and Business, 7(10), 35-42. https://doi. org/10.13106/jafeb.2020.vol7.no10.035

Qin, X., \& Zhou, C. (2019). Financial structure and determinants of systemic risk contribution. Pacific-Basin Finance Journal, 57(10), 101083. https://doi.org/10.1016/j.pacfin.2018.10.012

Sharpe, W. F. (1964). Capital asset prices: A theory of market equilibrium under conditions of risk. The Journal of Finance, 19(3), 425-442. https://doi.org/10.1111/j.1540-6261.1964. tb02865.x

Sheikh, N. A., \& Wang, Z. (2011). Determinants of capital structure: An empirical study of firms in manufacturing industry of Pakistan. Managerial Finance, 37(2), 117-133. https://doi. org/10.1108/03074351111103668

Srivastava, N. (2014). Determinants of Leverage of Indian Companies: An Empirical Analysis (A Study of Cement Industry in India). The International Journal of Business \& Management, 2(3), 49-53. https://www.meritresearchjournals. org/assh/index.htm

Tahir, S. H., Ullah, M. R., \& Mahmood, S. (2015). Banks Dividend Policy and Investment Decision as Determinants of Financing Decision: Evidence from Pakistan. American Journal of Industrial and Business Management, 5(5), 311-323. http:// dx.doi.org/10.4236/ajibm.2015.55032

Tahir, S. H., Ullah, M. R., \& Shah, D. S. (2017). What Determines Price-to-Earnings Ratios: An Empirical Evidence from Banking Sector of Pakistan. Journal of Business and Tourism, 3(1), 1322. https://www.awkum.edu.pk/jbt/downloads/Volume-03Number-01-Jan-June-2017/13\%20-\%2022.pdf

Tripathi, V., \& Thukral, S. (2018). Determinants of financing of outward foreign direct investment by Indian MNEs. International Journal of Emerging Markets 13(5), 1154-1181. https://doi.org/10.1108/IJoEM-12-2016-0333

Tulcanaza Prieto, A. B., \& Lee, Y. H. (2019). Internal and external determinants of capital structure in large Korean firms. Global Business \& Finance Review, 24(3), 79-96. https://doi. org/10.17549/gbfr.2019.24.3.79

Vivel-Búa, M., Lado-Sestayo, R., \& Otero-González, L. (2018). Risk determinants in the hotel sector: Risk credit in MSMEs. International Journal of Hospitality Management, 70, 110-119. https://doi.org/10.1016/j.ijhm.2017.11.004

Woo, S. H., Kwon, M. S., \& Yuen, K. F. (2020). Financial determinants of credit risk in the logistics and shipping industries. Maritime Economics \& Logistics, 3(1), 1-23. https:// doi.org/10.1057/s41278-020-00157-4 